\title{
PEDAGOGICAL CONDITIONS FOR CULTIVATING SIGNIFICANT PROFESSIONAL QUALITIES OF FUTURE SHIP OFFICERS IN THE PROCESS OF STUDYING HUMAN SCIENCES
}

The article deals with the issue of elaborating pedagogical conditions for cultivating significant professional qualities of future ship officers in the process of studying human sciences. We specify that the aforementioned pedagogical conditions comprise factors, circumstances and methods which determine effectiveness of educational process. Pedagogical conditions are defined as a peculiar way of organization of learning process that determines learning and educational results as well as development of significant professional qualities of future ship officers and gives a possibility to cultivate them. The pedagogical conditions for cultivating significant professional qualities of future ship officers in the process of studying human sciences are specified as follows: realization of personality-centered education of future ship officers tailored to the specific characteristics of the prospective professional environment marked with the condition of being isolated for a long time in a male multicultural society and overriding situations; preparing future ship officers for professional interaction by means of simulation communicative situations, hence obtaining knowledge of crew management, skills of working in a team, and ability to evaluate, anticipate and resolve conflict situations by taking part in trainings; carrying out assessment and self-assessment of level of professional qualities development among future ship specialists by using psycho-diagnostic methods. Pedagogical conditions are seen as a peculiar way of organizing the learning process, which determines achievements of education, level of cultivated professional qualities of future ship officers and also ensures a possibility to develop the listed items.

Key words: pedagogical conditions for cultivating significant professional qualities, significant professional qualities of future ship specialists.

Pedagogical basis of cultivating significant professional qualities of future ship officers consists in correlation between learning process, future professional activities and positive influence of human sciences. The latter maintain the process of professional qualities formation as well as foster the conditions eligible for their realization in the professional environment.

Raising of problem. The process of cultivating significant professional qualities of future ship officers through studying human sciences is rather complicated, since it includes knowledge of native language, world's cultural heritage, common humanity and social values. Besides, one must be familiar with essentials of pedagogy, psychology, sociology and other human sciences. System of knowledge of human sciences not only influences on the overall cultivation of the personality but also contributes to professional conceptualization of the mastery obtained. The cultivated professional qualities enable the future ship officers to make the correct focus and find a solution in different situations that they are going to encounter on board, cope with non-standard challenges and organize a positive environment which is conductive to keeping a good team work.

The article is aimed to highlight and specify pedagogical conditions for cultivating significant professional qualities of future ship officers.

Analysis of resent research and publications. The pedagogical conditions for cultivating significant professional qualities comprise factors, circumstances and methods which determine effectiveness of educational process. Cohesion of external pedagogical conditions and inner factors comprises the basis for cultivation of the personality by means of educational process. These constituencies must be taken into account to promote a good learning environment for all stages of learning, development and professional training.

The term "pedagogical conditions" encompass the aspects connected with organization of educational process which, in turn, constitutes an objective, forms, methods and means together with the interconnection of the process of cultivating significant professional qualities of future ship officers and training activities of teachers and cadets of maritime institutions. The conditions mentioned above are the reflection of structuring of knowledge, competencies and skills which can be applied for professional solutions of future ship officers. Investigating the issue of cultivating significant professional qualities of future ship officers through gaining specific knowledge, competencies and skills provides an opportunity to establish the conditions for professional self-realization. The process of cultivating significant professional qualities of future ship officers is particularly influenced by the content of special and psycho-pedagogical subjects including new scientific developments, best practices in various fields, such as pedagogy, psychology, foreign language, philosophy, sociology, etc. Learning of human sciences is carried out with respect to the principle of succession, which consists in theory followed by practice and is implemented at all stages of training process. 
Implementation of the described approach allows actualizing cultivation of significant professional qualities of future ship officers during educational period, makes them capable of self-realizing at work place, identifying, reasoning and resolving various professional matters encountered.

The encyclopedic dictionary defines the term "condition" as a complex of factors which influence living beings or lifeless things, creating the environment for something to happen. Conditions characterize various aspects of constant social factors [1:625].

The philosophical encyclopedic dictionary interprets "condition" as a complex of objects (items, processes, relations, etc.) necessary for genesis or existence of a change of a given object (that is under condition or conditional) [2: 286].

The philosophical dictionary specifies "condition" as a phenomenon affecting the other ones, making things, states and processes possible to exist. It is alike the cause, which inevitably, necessarily generates something (action, result of action), as well as the reason, that is a logical condition of the consequence [2]. Therefore, in philosophical terms the notion "condition" comprises the factors owing to which a phenomenon or process occurs and exists.

In psychology "condition" is understood as a complex of internal and external factors having an impact on development of a particular psychological phenomenon or process. When establishing the causal link of a particular phenomenon, it must be considered taking into account various links and relations, i.e. in overall relationship. If one phenomenon causes another, then it is a cause; if a phenomenon interacts with other one in the process of development of entity, to which it belongs, then it is a factor; if a phenomenon determines existence of another one, then it is a condition [3].

In the dictionary on education and pedagogy the term "condition" means a complex of variable natural, social, external and internal impacts which affect physical, psychological and moral development of the personality and behavior through education [4: 36].

V. Manko defines "pedagogical conditions" as an interdependent complex of internal parameters and external operational characteristics ensuring good performance of educational process and complying with psychological and pedagogical optimality criteria [5: 153-161].

It is pertinent to underline here that successful cultivating of significant professional features of future ship officers is impossible without positive motivation. According to V. Kuteeva, the positive motivation for the engagement of students involves sense of duty, understanding of importance of mastering professional skills, interest in education (human sciences particularly), sense of accomplishment when studying some new material and resolving difficult assignments. The motivation is also influenced by the content and methodology of classes, personality of the teacher, relationships in the micro-society, existence of competitive spirit and work with a view to results [6: 107].

During period of education at maritime academy, cadets obtain psychological preparation for their future work on board through studying human sciences. According to M. Nechaev and H. Riznytska, learning process occupies a key part of developing certain forms of mental activities, enabling resolution of various professional challenges in future [7: 4]. In the opinion of S. Smirnov, ability to study is one of the most important professional qualities, which a cadet must acquire while studying at a maritime academy, since the mentioned quality fundamentally determines his future professional career [8: 142].

Special qualities are particularly developed while studying at a high education institution. For the first time a cadet encounters various activities connected with his future profession. Therefore, dialogue forms must prevail in communication with senior cadets, namely, in the process of preparation of course papers, diploma projects and completing apprenticeship. The high education institution should apply the obtained knowledge and skills to develop self-sufficiency, the quality being very important for the future occupation, by means of active and creative forms of organization of learning process.

In this way, studying at a maritime academy takes place during crucial period of professional development of the personality affected by a complex of age and psychological factors. Cultivation of significant professional qualities of future ship officers takes place in the process of active learning process, that lies not only in obtaining some amount of knowledge, skills and competencies, but also in acquiring the significant qualities necessary for the future professional activities.

In pursuit of the objectives set in our research, it was made possible to evaluate the level of knowledge, motivation, personal needs, emotions, determined efforts and interests, along with the role of the mentioned concepts in cultivation of significant professional qualities of future ship officers in the process of studying human sciences. Besides, we would like to stress the importance of establishing the pedagogical conditions that will facilitate the professional growth of personality.

In our research work we pay attention to the guiding needs, which highlight ways and approaches to cultivation of significant professional qualities of future ship officers and their realization in future professional activities along with the impact on the personal life, i.e. the need of professional competency, interpersonal relationships, self-affirmation, realization and development. 
Another important aspect of our research work is the concept of "interest", which determines the process of cultivation of significant professional qualities of future ship officers. This is a category of pedagogy from the point of view of individual behavior changes, with a marked impact of human sciences. The latter are focused on enhancing of means, forms and methods of professional features formation. The investigation was carried out by means of observing, psycho-diagnostic methods, and analysis and synthesis of the cadets' environment in the course of their educational process through which direct communication with the academic staff and interaction are maintained.

Throughout education process at the maritime academy cadets acquire significant professional qualities, specific focus and intention to actualize the obtained knowledge, skills, competencies and practical experience in the chosen professional field owing to studying human sciences, special and other subjects as well as participating in social activities. The significant professional qualities forward professional determination of future ship officers, convey a positive attitude towards the chosen career path, keen interest in it, willing to improve the level of training and satisfy one's material and spiritual needs. Professional determination implies understanding and internal perception of missions and targets of future professional activities. All the features and components mentioned above present the professional determination indicator, characterized by stability (or instability), dominance of professional or personal motives.

Consequently, cultivation of significant professional qualities of future ship officers is done owing to providing cadets with the confidence in their professional fitness, awareness of importance of succeeding in all the subjects and training forms introduced in the curriculum of the academy. Besides, the ability to conduct selfeducation and knowledge improvement is recognized as an important one for maintaining the investigated process.

Based on the above, we figured out pedagogical conditions as a peculiar way of organizing the learning process, which determines achievements of education, level of cultivated professional qualities of future ship officers and also ensures a possibility to develop the listed items.

Results of research. The pedagogical conditions for cultivating significant professional qualities of future ship officers in the process of studying human sciences are specified as follows:

Realization of personality-centered education of future ship officers tailored to the specific characteristics of the prospective professional environment marked with the condition of being isolated for a long time in a male multicultural society and overriding situations;

Preparing future ship officers for professional interaction by means of simulation communicative situations, hence obtaining knowledge of crew management, skills of working in a team, and ability to evaluate, anticipate and resolve conflict situations by taking part in trainings;

Preparing future ship officers for professional interaction by means of simulation communicative situations, hence obtaining knowledge of crew management, skills of working in a team, and ability to evaluate, anticipate and resolve conflict situations by taking part in tailor-made trainings;

Carrying out assessment and self-assessment of level of professional qualities development among future ship specialists by using psycho-diagnostic methods.

The first condition was realized by means of the learning process, which determined achievements of education, level of cultivated professional qualities of future ship officers and individual constituent element of ontogenetic personality development influenced by such social factors as nurturing and education. Disciplines relating to human sciences include the activities crucially affecting the process of formation of professional qualities of future ship officers, i.e. level of communicative knowledge, skills and competencies, acquisition of cultural and spiritual values, norms which regulate social and communicative interaction between generations and nations, promote the aesthetic, moral and ethical development, formation of skills of free communication in different situations, ability to establish and defend one's point of view, hold discussions, evaluate various life situations, moral, social, historical and other issues of the present, and express one's attitude towards the abovementioned, reach a common understanding and interaction with other people. All these features are developed with the help of such subjects as Ukrainian language for specific purposes, History of Ukraine, History of Ukrainian culture, English language for specific purposes and Philosophy. Tolerant attitude to representatives of other nations, knowledge of culture's origins, different mentalities, ways of life, capability to maintain interpersonal relations on the basis of respect and find a compromise are built by the following subjects: History of Ukraine, Philosophy, Sociology, Psychology and Pedagogy. In addition the complex of human sciences facilitates self-control and stamina, aspects of management, such as work with a crew, solution to the conflict situations through Psychology; building up a personal program of development, which is helpful in finding one's place in life, becoming successful in the professional sphere through Psychology, Pedagogy, English language for specific purposes; ability to get oriented and used to new conditions of life, govern them in a constructive way; setting one's status in the given social group, cooperation with other crewmembers, ability to prevent conflicts and fair treatment of the shipmates through Psychology, Pedagogy and Sociology.

The second condition was realized through the study of the special subject, called "Psychological and pedagogical aspects of cooperation in a crew", which covers the following issues: obtaining knowledge and skills 
in the field of crew management and cooperation, methods for ship officers to influence their subordinates; reputation, that is the development of self-confidence, factors affecting officer's reputation; ways of cooperation in a team which constitute sources of management, methods of influence on the subordinates; management styles. This academic subject is aimed to develop critical evaluation of one's life and professional experience, realize choosing ways and methods of improvement of personal features and professional skills; ability to work efficiently in a team, be heuristic and sociable, develop one's skills of integration and self-regulation, build a positive professional identity owing to the specific activities, establish and resolve various professional assignments and coping with problematic situations, self-determination realization and affirmation, constant personal improvement, present adequate self-evaluation; become aware of ethic and deontological code of conduct, teach to plan and control learning activities, nurture proactivity and persistence, get understanding on how to draw up the basic and perspective professional plans.

The third condition was realized in the process of assessment and self-assessment of level of professional qualities development among future ship officers. On using psycho-diagnostic methods there was carried out data collection and processing by means of program SPSS-20, which provides an opportunity to group the obtained results into factors determining the significant professional features that have already been formed and the ones to be improved in the process of passing specific trainings. Grouping of the factors must be done with regard to individual psychological features of cadets.

Conclusion. In conclusion, application of all the opportunities of training process contributes to achievement of the objective to cultivate significant professional qualities of future ship officers necessary for professional self-realization and development conducted owing to the obtained knowledge, skills and competencies.

\section{СПИСОК ВИКОРИСТАНИХ ДЖЕРЕЛ ТА ЛІТЕРАТУРИ}

1. Советский энциклопедический словарь / гл. ред. А. М. Прохоров. - 3-е изд. - М. : Сов. энциклопедия, 1985. $1600 \mathrm{c}$.

2. Філософський словник / за ред. В. І. Шинкарука. - 2-е вид., переробл. і доповн. - К. : УРЕ, 1986. - 800 с.

3. Психологическая энциклопедия / под ред. Р. Корсини, А. Ауэрбаха. - [2-е изд.]. - СПб. : Питер, 2006. $1096 \mathrm{c}$.

4. Энциклопедия профессионального образования : в 3 т. Т. 2 / [под ред. С. .Я.. Батышева]. - М. : АПО, 1999. $440 \mathrm{c}$.

5. Манько В. М. Дидактичні умови формування у студентів професійно-пізнавального інтересу до спеціальних дисциплін / В. М. Манько // Соціалізація особистості: [3б. наук. пр. національного педагогічного університету ім. М. Драгоманова]. - К., 2000. - Вип. 2. - С. 153-161.

6. Кутеева В. П. Формирование познавательной активности будущих специалистов / В. П. Кутеева // Психологические проблемы формирования специалиста в вузе : [межвуз. сб. науч. труд.]. - Саранск, 1999. C. $105-109$.

7. Нечаев Н. Н. Профессиональное сознание как предмет психолого-педагогического исследования в высшей школе / Н. Н. Нечаева, Г. И. Резницкая // Психологические проблемы формирования специалиста в вузе : [межвуз. сб. науч. труд.]. - Саранск, 1989. - С. 4-15.

8. Смирнов С. Д. Педагогика и психология высшего образования: от деятельности к личности / С. Д. Смирнов. - М. : Академия, 2001. - 304 с.

9. Галузинський В. Г. Основи педагогіки та психології вищої школи: навч. посібник для викладачів та аспірантів вузів / В. Г. Галузинський, М. Б. Євнух. - К. : ІНТЕЛ., 1995. - 168 с.

10. Ігнатюк О. А. Педагогічні умови забезпечення особистісної орієнтації підготовки гуманітарно-технічної еліти / О. А. Ігнатюк // Педагогіка і психологія професійної освіти. - 2002. - № 6. - С. 82-87.

\section{REFERENCES (TRANSLATED \& TRANSLITERATED)}

1. Sovetskii entsiklopedicheskii slovar' [Soviet Encyclopedic Dictionary] / gl. red. A. M. Prokhorov. - Moscow : Sov. Entsyclopediia, 1985. - $1600 \mathrm{p}$.

2. Filosofs'kyi slovnyk [Dictionary of Philisophy] / za red. V. I. Shynkaruka. - Kyiv : Ure, 1986. - 800 p.

3. Psikhologicheskaia entsiklopediia [Encyclopedia of Psychology] / pod red. R. Korsini, A. Auerbakh. - [2-e izd.]. S. Petersburg : Piter, 2006. -1600 p.

4. Batyshev S. Ya. Entsiklopediia professional'nogo obrazovaniia [Encyclopedia of Professional Education]. Moscow : Apo, 1999. - 440 p.

5. Manko V. M. Dydaktychni umovy formuvannia u studentiv profesiino-piznaval'nogo interesu do special'nykh dystsyplin [Didactic Conditions of Developing Learning Interest in Specific Subjects] // Socializatsiia osobystosti [Socialization of Personality]. - 2002. - No 2. - Pp. 153-161.

6. Kutieieva V. P. Formirovanie poznavatel'noi aktivnosti budushchikh spetsialistov [Fostering the Learning Interest among Future Specialists] // Psikhologicheskiie problemy formirovaniia spetsialista v vuze [Psychological Issues of Specialist's Development during University Years]. - Saransk, 1999. - Pp. 105-109.

7. Nechaiev N. N. Professional'noe soznanie kak predmet psikhologo-pedagogicheskogo issledovaniia v vysshei shkole [Professional Awareness as a Subject of Pedagogic Investigation at a Higher Education Institution] / N. N. Nechaiev // Psikhologicheskiie problemy formirovaniia spetsialista v vuze [Psychological Issues of Specialist's Development during University Years]. - Saransk, 1999. - Pp. 4-15. 
8. Smirnov S. D. Pedagogika i psikhologiia vysshego obrazovaniia: ot deiatel'nosti k lichnosti [Pedagogy and Psychology of Higher Education : From Activity to Personality] / S. D. Smirnov. - Moscow : Academia, 2001. $304 \mathrm{p}$.

9. Ghaluzynskyi V. Gh. Osnovy pedagogiky ta psykhologii vyshhoi shkoly [Basics of Pedagogy and Psychology for Higher Education] / V. Gh. Ghaluzynskyi. - Kyiv : Intel, 1995. - 168 p.

10. Ighnatiuk O. A. Pedaghoghichni umovy zabezpechennia osobystisnoi oriientatsii pidghotovky ghumanitarnotekhnichnoi elity [Pedagogical Conditions for Training of Specialists in the Field of Human and Technical Sciences]/ O. A. Ighnatiuk // Pedagogika i psykhologiia profesiinoi osvity [Pedagogy and Psychology of Professional Training]. - 2002. - No. 6. - Pp. 82-87.

\section{Бабишена М. І. Педагогічні умови формування професійно значущих якостей майбутніх суднових офіцерів у процесі вивчення суспільно-гуманітарних дисциплін.}

У статті представлена проблема розробки педагогічних умов формування професійно значущих якостей майбутніх суднових офіџерів у прочесі вивчення суспільно-гуманітарних дисциплін. Визначено

педагогічні умови як особливості організачії навчального процесу, який детермінує результати навчання, освіти та розвитку професійно значущих якостей майбутніх суднових офіцерів і об'єктивно забезпечує можливість їх формування.

Ключові слова: педагогічні умови формування професійно значущчих якостей, професійно значущі якості майбутніх суднових фахівців.

\section{Бабышена М. И. Педагогические условия формирования профессионально значимых качеств будущих судовых офицеров в процессе изучения общественно-гуманитарных дисциплин.}

В статье представлена проблема разработки педагогических условий формирования профессионально значимых качеств будущих судовых офицеров в процессе изучения общественно-гуманитарных дисциплин. Определень педагогические условия и особенности организации учебного процесса, который детерминирует результаты обучения, образования и развития профессионально значимых качеств будущих судовых офищеров и объективно обеспечивает возможность их формирования.

Ключевые слова: педагогические условия формирования профессионально значимых качеств, профессионально значимые качества будущих судовых специилистов. 